of hydrochloric acid and heat to dissolve the residue. Transfer the solution into a volumetric flask $(200 \mathrm{ml})$. Adjust the volume to $200 \mathrm{ml}$ with water and introduce $10 \mathrm{ml}$ portion of the diluted solution into the generator. Add $10 \mathrm{ml}$ of hydrochloric acid, $3 \mathrm{ml}$ of sulfuric acid, $1 \mathrm{ml}$ of potassium iodide solution $(200 \mathrm{~g} / l)$ and $2 \mathrm{ml}$ of stannous chloride solution $(200 \mathrm{~g} / l)$, and let stand for 10 minutes. Add $1 \mathrm{~g}$ of zinc powder and immediately connect the generator to the atomic absorp- tion spectrometer. Measure the absorbance of resonance line of arsenic at $193.7 \mathrm{~nm}$.

The standard deviations of this method were $0.000 \sim$ $0.003 \mathrm{ppm}$ at the level of $0.004 \sim 0.083 \mathrm{ppm}$ for waste water and $0.0001 \sim 0.0002 \%$ at the level of $0.0014 \sim$ $0.0036 \%$ for soils. Sensitivity was $0.02 \mu \mathrm{g}$ (1\% absorbance).

(Received Jan. 22, 1973)

\title{
カルシウムの同位体希 䣋質量分析*
}

\author{
室住 正世, 中村 精次**
}

(1973 年 3 月 22 日受理)

\begin{abstract}
${ }^{42} \mathrm{Ca}$ 濃縮同位体をスパイクとして用いる同位体希釈，表面電離質量分析法により，蒸留水，脱イオ ン水, 特に地球南北両極雪氷中の $\mathrm{ppb}$ 濃度のカルシウムを, 試料 10 ないし $20 \mathrm{~g}$ によって定量した. イオンソース部にタンタルのシングルフィラメントを用い, その電流の精密制御をはかった結果, 比較 的低電流值において強度の大きいイオンビームを得て, 感度を $10^{-10} な い し 10^{-11} \mathrm{~g}$, イオンビーム強 度比の測定における変動係数を 0.22 ないし $0.66 \%$ とすることができた。

${ }^{40} \mathrm{Ca}+$ に重複する ${ }^{40} \mathrm{~K}+$ は, ベーキング処理によって除去することができた.

これを両極雪氷の地球化学的研究に応用して, 地域差, 季節变化, 経年变化, カルシウムの存在状態 など降雪の機構について知見を得ることができた.
\end{abstract}

\section{1 緒 言}

南極大陸やグリーンランド内陸の雪氷中のカルシウム 濃度は ppb 程度にすぎない. この氷床中に深層ボーリ ングが行なわれ，雪氷学的1)，地球化学的に多目的をも つ試料が採取されているが，コア直径が 7 ないし $10 \mathrm{~cm}$ のものであるから化学成分の定量に供試できる試料量に も制約があるのはやむをえないことである.1 か月分の 降雪を独占して供試するとしても，コアの厚みとして $1 \mathrm{~cm}$, 重さとして 20 ないし $30 \mathrm{~g}$, 含有されるカルシ ウム量は 10-7ないし 10-8 $\mathrm{g}$ である.

${ }^{42} \mathrm{Ca}$ 濃縮同位体をスパイクとして用いる同位体希釈 法を, 表面電離形質量分析計によって行なうことにより, 10-10 ないし $10^{-11} \mathrm{~g}$ の感度をもってこの種の雪水試料 や脱イオン水, 再蒸留水などの分析が可能となった. 質

* 地球両極水雪中の $\mathrm{ppb}$ 濃度の化学成分分析法 (第 4 報). 前報は室住正世，中村精次：本誌，22，145 (1973)

** 室蘭工業大学 : 北海道室蘭市水元町 27
量分析用の試料量をなるべく少量ですませるためイオン 源はタンタルのシングルフィラメントを用いたが，フィ ラメント電流值の微調整に配虑した. その結果, ${ }^{42} \mathrm{Ca}+$ / ${ }^{40} \mathrm{Ca}+$ を変動係数 [標準偏差/平均值] が 0.22 ないし $0.66 \%$ で測定できた.なお化学処理を含むくりかえし 分析の誤差は 1.5 ないし $6 \%$ の程度となった. 分析所 要時間は 1 昼夜である.

\section{2 装置および実験}

\section{1 兵量分析計}

日立製作所製 RMU 6 形（イオン軌道半径 $20 \mathrm{~cm}$, シングルコレクター，磁場走査方式）を使用したが，前 報記載2）のように，特にイオン源部のシングルフィラメ ソトの電流を $1 \mathrm{~mA}$ きざみで昇降でき $10^{-2} \mathrm{~mA}$ の精度 が保てるようにして, カルシウムのイオン化が定常的に なるようくふうした。質量分析のスペクトルとしては， タンタルフィラメント上のカルシウム（主として硝酸 塩, 硫酸塩で塩化物も混在) 化合物より発せられる $\mathrm{Ca}^{+}$ を対象とした. $\mathrm{Ca}+$ ビームは加速電圧 $(3600 \mathrm{~V})$, 磁場 (0〜8000 gauss，モータースキャン方式）を経て質量ス ペクトル化され，2 次電子増倍装置 (10 段増幅, 印加 
Table I Determination of calcium in redistilled water

\begin{tabular}{|c|c|c|c|c|c|c|c|c|}
\hline \multirow{2}{*}{ Run } & \multirow{2}{*}{$\begin{array}{l}\text { Sample taken } \\
(\mathrm{g})\end{array}$} & \multirow{2}{*}{$\begin{array}{c}{ }^{42} \mathrm{Ca} \text { added } \\
\left(10^{-7} M\right)\end{array}$} & \multicolumn{2}{|c|}{ Filament current } & \multirow{2}{*}{$\begin{array}{c}{ }^{42} \mathrm{Ca}^{+} /{ }^{40} \mathrm{Ca}^{+} \\
\text {measured }\end{array}$} & \multirow{2}{*}{$\begin{array}{l}\text { C. V.tt' } \\
(\%)\end{array}$} & \multirow{2}{*}{$\begin{array}{l}\text { Ca found } \\
\left(10^{-8} M\right)\end{array}$} & \multirow{2}{*}{$\begin{array}{l}\text { Ca concn. } \\
\text { (ppb) }\end{array}$} \\
\hline & & & $\alpha \dagger(\mathrm{A})$ & $\beta+t$ (A) & & & & \\
\hline 1 & 60.32 & 0.309 & 1.21 & 1.69 & 6.65 & 0.14 & 0.296 & 1.97 \\
\hline 2 & 60.24 & 0.332 & 1.13 & 1.67 & 7.08 & 0.27 & 0.287 & 1.92 \\
\hline 3 & 30.28 & 0.248 & 1.05 & 1.66 & 8.77 & 0.11 & 0.153 & 1.98 \\
\hline 4 & 30.00 & 0.255 & 1.15 & 1.68 & 9.16 & 0.085 & 0.143 & 1.89 \\
\hline
\end{tabular}

$\dagger$ Filament current, $\mathrm{A}$, at which the detectable calcium ion beam appeared. The detection limit was about $10^{-10} \mathrm{~g}$. $\dagger \dagger$ Filament current, $\mathrm{A}$, at which the maximum intensity of calcium ion beam was recorded. †† Coefficient of variation, standard deviation/ average, in measurements of ${ }^{4} \mathrm{Ca}^{+} /{ }^{4} \mathrm{Ca}^{+}$peak height ratio

電圧 $2500 \mathrm{~V}$, 増幅率 1250 倍) で増幅後ペン記録され る. プレフンプの高抵抗に $10^{11} \Omega$ を使用した場合，記 録紙上で $1 \mathrm{~V}$ のピークの高さを示す $\mathrm{Ca}^{+}$のイオンビー ムは 10-14 A に相当する. 本報では, この条件で測定し たピークの高さよりイオンビームの強さを求めて表示し た. 実験条件の違う場合は，その結果を上記条件に規格 化した。

\section{2 実験, 再蒸留水中のカルシウム定量}

2.2.1 試料金属製蒸留装置と石英製 2 段連続式蒸 留装置とを連結したものから，0.3 l/時間の割合で得た $15 l$ を $20 l$ 容量の白色ポリエチレンびん中に 1 か月保 存し, 比抵抗が $5 \times 10^{6} \Omega \mathrm{cm}$ であるものを分析対象とし た.

2.2.2 試料調製と原理 器具類はすべて前報2)に記 載の方法により用意した. Table II の同位体比（原子 比）と濃度とをひつ ${ }^{42} \mathrm{Ca}$ スパイク溶液を ${ }^{42} \mathrm{Ca}^{2}+$ が $0.3 \times 10^{-7}$ モル程度, $100 \mathrm{ml}$ 容量のテフロンビーカー 中に正確にはかりとる. これに試料水を $60 \mathrm{~g}$ と $30 \mathrm{~g}$ は かり加える [Table I, \{雪氷試料の分析 (3.3.1) では, $20 \mathrm{~g}$ と $10 \mathrm{~g}\}$ ]. この溶液を窒素気流中で蒸発濃縮して 約 $50 \mu l$ としたものを質量分析用の試料とする. 石英 製微量ピペットを用いてその一部をイオン源のタンタル フィラメントの中央部に移しのせ, 空気中で通電加温し て蒸発乾固させる.フィラメント上のカルシウムは，ス パイク中に加えられた硝酸のため主として硝酸カルシウ ムとして存在すると考えられる. 雪氷試料 (3.3.1) で は試料中に硫酸イオン, 塩素イオンがカルシウムに対し 多量に存在するから, 硫酸カルシウム, 塩化カルシウム

Table II Concentration and composition of stock and working ${ }^{42} \mathrm{Ca}$ spike solutions

\begin{tabular}{lcc}
\hline & Stock solution & Working solution \\
\hline Concentration & $250.0 \mu \mathrm{g} / \mathrm{g}$ & $20.84 \mu \mathrm{g} / \mathrm{g}$ \\
${ }^{4} \mathrm{Ca}$ & $5.67 \times 10^{-6} \mathrm{~mol} / \mathrm{g}$ & $0.473 \times 10^{-6} \mathrm{~mol} / \mathrm{g}$ \\
${ }^{4} \mathrm{Ca}$ & $0.298 \times 10^{-6} \mathrm{~mol} / \mathrm{g}$ & $0.0248 \times 10^{-6} \mathrm{~mol} / \mathrm{g}$ \\
${ }^{4} \mathrm{Ca} /{ }^{4}{ }^{0} \mathrm{Ca} \dagger$ & $19.0_{0}$ & $19.0_{8}$ \\
\hline$\dagger$ Atomic ratio & &
\end{tabular}

が硝酸カルシウムに混在することになる、 ${ }^{42} \mathrm{Ca}$ と ${ }^{40} \mathrm{Ca}$ とには原子比で次式の関係が存在する.

$$
\frac{{ }^{42} \mathrm{Ca}}{{ }^{40} \mathrm{Ca}}=\frac{{ }^{42} \mathrm{f} \cdot x+{ }^{42} \mathrm{Ca}(\mathrm{s})}{{ }^{40} \mathrm{f} \cdot x+{ }^{40} \mathrm{Ca}(\mathrm{s})}
$$

42f, ${ }^{40} \mathrm{f}$ は試料中のカルシウムの同位体比, $x$ は求める カルシウムのモル数, ${ }^{42} \mathrm{Ca}(\mathrm{s}),{ }^{40} \mathrm{Ca}(\mathrm{s})$ はスパイクとし て加えられた ${ }^{42} \mathrm{Ca}$ と ${ }^{40} \mathrm{Ca}$ のモル数を示す. 本報では 42f， ${ }^{40}$ をとれぞれ 0.64\%，96.97\%とした3). ${ }^{42} \mathrm{Ca} /$ ${ }^{40} \mathrm{Ca}$ 質量分析して求めれば $x$ を知ることができる。

\subsection{3 ${ }^{42} \mathrm{Ca}$ スパイク溶液 ORNL*製の ${ }^{42} \mathrm{CaCO}_{3}$} を $0.0631 \mathrm{~g}$ はかりとり，20\% の温硝酸の $10 \mathrm{~g}$ に溶か したのち, 蒸留水で希釈して $103.24 \mathrm{~g}$ とし白色ポリエ チレンびん中に保存した. 使用した硝酸と蒸留水中のカ ルシウム濃度はそれぞれ $2.51 \mathrm{ppb}$ と $1.30 \mathrm{ppb}$ であっ た (3.1 および Table V). この原液を希釈して実用の ${ }^{42} \mathrm{Ca}$ スパイク溶液, Table II を調製したが, 同位体比 の実測結果は ORNL の保証值と一致した (Table III).

Table III Isotopic compositiont of the working ${ }^{42} \mathrm{Ca}$ spike

\begin{tabular}{|c|c|c|c|c|c|c|}
\hline Run & $\begin{array}{l}\text { Filament } \\
\text { current } \\
\text { (A) }\end{array}$ & $\begin{array}{c}{ }^{40} \mathrm{Ca}^{+} \text {ion } \\
\text { beam current } \\
\left(\times 10^{-14} \mathrm{~A}\right)\end{array}$ & $\begin{array}{c}{ }^{40} \mathrm{Ca} \\
(\%)\end{array}$ & $\begin{array}{c}{ }^{42 \mathrm{Ca}} \\
(\%)\end{array}$ & $\begin{array}{r}43 \mathrm{Ca} \\
(\%)\end{array}$ & $\begin{array}{r}{ }^{44} \mathrm{Ca} \\
(\%)\end{array}$ \\
\hline 1 & 2.250 & 3.12 & 5.04 & 94.3 & 0.0689 & 0.557 \\
\hline 2 & 2.250 & 3.24 & 4.95 & 94.4 & 0.0695 & 0.562 \\
\hline 3 & 2.250 & 3.24 & 4.92 & 94.5 & 0.0700 & 0.562 \\
\hline 4 & 2.250 & 3.28 & 4.89 & 94.5 & 0.0705 & 0.566 \\
\hline Average & & & 4.95 & 94.4 & 0.0697 & 0.563 \\
\hline ORNL + & . & & 4.96 & 94.42 & 0.0693 & 0.563 \\
\hline
\end{tabular}

（1）兵贵分析 イオン源タンタルフィラメントの電 流值を 1 ないし $3 \mathrm{~mA} / \mathrm{min}$ の割合で上昇させると約 0.6 $\mathrm{A}$ で $\mathrm{K}+$ のビームが出現するが， 0.7A で ${ }^{39} \mathrm{~K}+$ イオ ンビームは $10^{-13} \mathrm{~A},{ }^{40} \mathrm{~K}+$ イオンビームは $10^{-17} \mathrm{~A}$ と

* Oak Ridge National Laboratory, Oak Ridge, Tenn., U. S. A, 
なった. このように蒸留水源のカリウム（その濃度は $\left.0.18 \mathrm{ppb}^{2)}\right)$ は強いイオンビームを発するが，フィラメ ント電流值が 0.9 ないし $1.0 \mathrm{~A}$ になるまでにはカリウ ム化合物の蒸発消失によって減衰してしまう.すなわち ${ }^{40} \mathrm{Ca}+$ の同重体としての ${ }^{40} \mathrm{~K}+$ はフィラメント電流値の 上昇操作の初期段階で消滅してしまい悪影響を残さな い.フィラメント電流值が $1.1 \mathrm{~A}$ 程度になるとはじめて $\mathrm{Ca}^{+}$のイオンビームが出現し, その後はフィラメント 電流值の上昇に対応して階段的に強度を増大寸る. この 過程で前報記載のイオンビーム強度の急増現象が発現す るから，それを確実には握することが，フィラメント電 流值が低い領域で強いイオンビームを得るために必要で ある. フィラメント電流值が 1.6 ないし $1.7 \mathrm{~A} て ゙ \mathrm{Ca}^{+}$ イオンビームの強度は極大に達し, その後は試料の蒸発 とともに急速に減衰してしまう。しかし硫酸分析の場合 には (Table V), テフロンビーカーの内壁が溶出して 炭化し, フィラメント上におけるカルシウムのイオン化 を妨害し, 極大值の現われるフィラメント電流值が $2 \mathrm{~A}$ をこえることもある．海水のように試料が有機物を含む 場合も同様である (Table VI). イオンビームの強度が 極大に近づき安定に維持される期間に ${ }^{42} \mathrm{Ca}^{+} /{ }^{40} \mathrm{Ca}+$ を 10 対以上求めた (Table IV). なお, この場合に ${ }^{39} \mathrm{~K}+$ または ${ }^{41} \mathrm{~K}+$ を記録して, ${ }^{40} \mathrm{~K}+$ の影響のないことを確 認した.

（2）検出感度 Table IV には Table I の Run 1 のイオンビーム量 $\mathrm{A}$ を表示したが， ${ }^{42} \mathrm{Ca}+$ の極大值は $9.11 \times 10^{-14} \mathrm{~A}$ である. この極大值は, 式 (1) におけ る ${ }^{42} \mathrm{Ca}(\mathrm{s})=0.309 \times 10^{-7}$ モルと ${ }^{42} \mathrm{f} \cdot x=0.018 \times 10^{-7}$ モ

Table IV Determination of calcium in redistilled water ( $c f$. Run 1 in Table I)

\begin{tabular}{cccc}
\hline \hline $\begin{array}{c}\text { Time (min) after } \\
\text { onset of filament } \\
\text { current }\end{array}$ & \multicolumn{2}{c}{ Ion beam current } & \\
\hline 600 & $4^{40 \mathrm{Ca}^{+}}$ & ${ }^{42 \mathrm{Ca}^{+} /}$ \\
${ }^{4} \mathrm{Ca}^{+}$ & ${ }^{2} \mathrm{Ca}^{+}$ & \\
\hline 604 & 1.365 & 9.11 & 6.67 \\
608 & 1.355 & 9.03 & 6.66 \\
612 & 1.332 & 8.85 & 6.65 \\
616 & 1.302 & 8.66 & 6.65 \\
620 & 1.274 & 8.49 & 6.66 \\
624 & 1.258 & 8.36 & 6.65 \\
628 & 1.229 & 8.17 & 6.65 \\
632 & 1.208 & 8.04 & 6.66 \\
636 & 1.182 & 7.87 & 6.66 \\
640 & 1.153 & 7.66 & 6.64 \\
644 & 1.118 & 7.44 & 6.65 \\
670 & 1.094 & 7.26 & 6.64 \\
Average & 0.999 & 6.64 & 6.65 \\
\hline
\end{tabular}

Filament current was kept constant, $1.690 \mathrm{~A}$, through the measurements; $\dagger$ Coefficient of variation $=0.14 \%$
ルの和，すなわち $0.327 \times 10^{-7}$ モルの ${ }^{42} \mathrm{Ca}$ にって 与えられている. イオンビーム量の検出限度は $0.2 \times$ $10^{-17} \mathrm{~A}$ であるから，この場合， $7.2 \times 10^{-13}$ モルすなわ ち $2.9 \times 10^{-11} \mathrm{~g}$ の ${ }^{42} \mathrm{Ca}$ がそれに相当する. 検出感度 をこのように意味づけると, その数值はフィラメント上 におけるカルシウムの存在形やフィラメント電流值の上 昇法などにより影響を受けやすいものであるが，本法で は一般に $10^{-10} \sim 10^{-11} \mathrm{~g}$ となった。

（3）精度 Table I の Run 4 はイオンビームの強 度が安定に維持された場合の ${ }^{42} \mathrm{Ca}+/{ }^{40} \mathrm{Ca}+$ の測定結果 に基づいている. この場合, ${ }^{42} \mathrm{Ca}+$ と ${ }^{40} \mathrm{Ca}+$ のイオン ビームは, フィラメント電流值 $1.680 \mathrm{~A}$ で極大值 4.89 $\times 10^{-14} \mathrm{~A}$ と $0.533 \times 10^{-14} \mathrm{~A}$ とに達したのち，30 分間, $(4.88 \pm 0.01) \times 10^{-14} \mathrm{~A}$ と $(0.533 \pm 0.002) \times 10^{-14} \mathrm{~A}$ と に維持された. この間における ${ }^{42} \mathrm{Ca}+/{ }^{40} \mathrm{Ca}+$ の平均值 は 9.16 で変動係数は $0.085 \%$ となった. これに対し Table IV は, イオンビームの強度の变動時における測 定結果で， ${ }^{42} \mathrm{Ca}+$ と ${ }^{40} \mathrm{Ca}+$ のイオンビームはそれぞれ $9.11 \times 10^{-14} \mathrm{~A}, 1.365 \times 10^{-14} \mathrm{~A}$ より $6.64 \times 10^{-14} \mathrm{~A}$, $0.999 \times 10^{-14} \mathrm{~A}$ へと約 $25 \%$ の減衰を示したものである が， その間の ${ }^{42} \mathrm{Ca}^{+} /{ }^{40} \mathrm{Ca}^{+}$は平均值が 6.65 で変動係 数は $0.14 \%$ に保たれた. この精度は式（1）を解くの に必要じゅうぶんなものと考えられる.

変動係数の小さい ${ }^{42} \mathrm{Ca}+/{ }^{40} \mathrm{Ca}+$ を得るためには，な るベく低いフィラメント電流值で強度の高いイオンビー ムを得ることが必要である. 特に本法では, 強度の低い ${ }^{40} \mathrm{Ca}+$ の読夕取りの誤差に影響されることが大きい. 変 動係数を小さくするためには ${ }^{42} \mathrm{Ca}^{+} /{ }^{40} \mathrm{Ca}+$ を 1 に近づ ければよいが，そのためには試料量を $400 \mathrm{~g}$ とせねばな らずかえって本法の本質を失うこととなる，本報では ${ }^{42} \mathrm{Ca}+/{ }^{40} \mathrm{Ca}+$ が 10 内外の值をとるよう試料量を調整し て, Table I に示すように変動係数を $0.3 \%$ 以内にと どめることができた.

（4）同位体効果 ${ }^{42} \mathrm{Ca}^{+} /{ }^{40} \mathrm{Ca}+$ の值には，測定時間 が長時間にわたり，特にフィラメント電流值に相違が生 じたりすると同位体効果が現われ，平均值に対して偏差 が 4\%にも及ぶことがある. その程度は，フィラメント 電流值, カルシウム量, ${ }^{42} \mathrm{Ca}^{+} /{ }^{40} \mathrm{Ca}^{+}$の值によるとこ ろが多い，本報では， ${ }^{42} \mathrm{Ca}$ スパイクのはかりとり量を $1 \mu \mathrm{g}$ 程度に統一し, ${ }^{42} \mathrm{Ca}^{+} /{ }^{40} \mathrm{Ca}^{+}$が約 10 になるよう 試料量を調整し，またフィラメント電流值が 1.6 ない $1.8 \mathrm{~A}$ でイオンビームの強さが極大になるようにした結 果, 同位体効果に基づく偏差を $1 \%$ 以内にとどめること ができた. 式（1）において, ${ }^{42} \mathrm{Ca}+/{ }^{40} \mathrm{Ca}+$ の值の $\pm 1 \%$ のかたよりは $x$ に対し最大で $\pm 2 \%$ の誤差を生じさせ 
るが，本法の有効性を阻害するものとはなっていない，

（5）〈りかえし分析精度 Table I の結果は試料量 のみを $60 \mathrm{~g}$ と $30 \mathrm{~g}$ とに变え, 他の条件はほぼ同一にし て得たものである.すなわち, 試料調製時における污染 源への 暴露の程度やカリウムなどの 共存成分量に $2: 1$ の大小関係をもつ試料について $x$ を求めたものである.

${ }^{42} \mathrm{Ca}^{+} /{ }^{40} \mathrm{Ca}^{+}$の質量分析にも精度の差 がある 条件下で あるが， $x$ 值はそれぞれ $(0.292 \pm 0.006) \times 10^{-8}$ モルと $(0.148 \pm 0.005) \times 10^{-8}$ モルとなり，濃度としてそれぞ

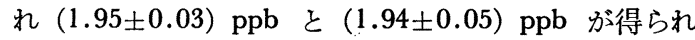
た. Table I で, 試料採取量を $0 \mathrm{~g}$ に外そうした $x$ 值は $\pm 0.0003 \mu \mathrm{g}$ となり，試料調製より質量分析にわたる誤 差を示している.

(6) カリウムの妨害 カルシウムのイオンビームの 強度が記録されるフィラメント電流值で, カリウムのイ オンビームが認められることがある．この種の污染源や メモリー効果によるカリウムのイオンビームは, 最大で も ${ }^{39} \mathrm{~K}+$ で $0.1 \times 10^{-14} \mathrm{~A}$ で ${ }^{40} \mathrm{~K}+$ としては $10^{-18} \mathrm{~A}$ 程度である. ${ }^{40} \mathrm{Ca}+$ イオンビームの $10^{-5}$ にすぎず，妨 害はない(Table V).

$$
3 \text { 応用 }
$$

\section{1 試薬中のカルシウム}

市販特級品の硝酸, 塩酸, 過塩素酸を石英装置で再蒸 留した分析結果を Table V に示す. 硫酸は特級品をそ
のまま供試した. Table V 中の再蒸留水をスパイクの 調製に利用した。

\section{2 海水中のカルシウム}

Table VI に試料量 $5 \mu l$ および $10 \mu l$ 程度のくりか えし分析結果を示す. カルシウムの $x$ 值式 (1), Table VI では Ca found $10^{-8} M$ が Table I に比べ 100 倍 量の領域でも本法が成立することを示している．カルシ ウムに対し，およそ同量のカリウム，3 倍量のマグネシ ウム, 20 倍量のナトリウム, 有機物など共存成分の影 響は，フィラメント電流值を多少高くするにとどまっ た。

\section{3 極地雪永中のカルシゥム}

3.3.1 試料 West Enderby Land の試料は南極観

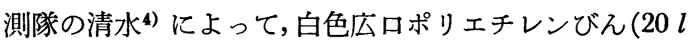
容量）に 4 ないし $9 \mathrm{~kg}$ 採取された. 東京港に帰着後に 自然融解し，分析完了までに 2 か月を要した. 主成分濃 度を Table VII にあげたが，ナトリウムとマグネシウ ムは冷凍濃縮原子吸光法5)，カリウムとチタンは同位体 希釈表面電離質量分析法2)6）により定量した。主成分ナ トリウムに対するカルシウムの原子比を Table VIII に 示したが，欄外の海水および極地水の数值も本法によっ た.

試料採取，保存などに使用した用具，容器類の洗浄法

Table V Determination of calcium in some reagents and pure water

\begin{tabular}{|c|c|c|c|c|c|c|c|c|c|}
\hline & $\begin{array}{c}\text { Sample } \\
\text { taken } \\
(\mathrm{g})\end{array}$ & $\begin{array}{c}{ }^{42 \mathrm{Ca}} \\
\text { spike added } \\
\left(10^{-7} M\right)\end{array}$ & 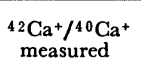 & c. V.† & $\begin{array}{l}\text { Ca found } \\
\left(10^{-8} M\right)\end{array}$ & $\begin{array}{l}\text { Ca concn. } \\
(\mathrm{ppb})\end{array}$ & $\begin{array}{l}\text { Filament } \\
\text { current } \\
\text { (A) }\end{array}$ & $\begin{array}{c}{ }^{42} \mathrm{Ca}^{+} \text {ion } \\
\text { beam current } \\
\left(\times 10^{-14} \mathrm{~A}\right)\end{array}$ & $\begin{array}{l}{ }^{40} \mathrm{~K}^{+} \text {ion } \\
\text { beam current } \\
\left(\times 10^{-17} \mathrm{~A}+\dagger\right)\end{array}$ \\
\hline $\mathrm{HCl}$ & 11.29 & 0.267 & 10.7 & 0.88 & 0.113 & 3.84 & 1.660 & 4.48 & 0.55 \\
\hline $\mathrm{HNO}_{3}$ & 6.37 & 0.255 & 14.6 & 0.90 & 0.042 & 2.51 & 1.670 & 2.37 & 0.05 \\
\hline $\mathrm{HClO}_{4}$ & 7.37 & 0.288 & 17.2 & 3.0 & 0.0017 & 0.88 & 1.980 & 1.23 & 0.26 \\
\hline $\mathrm{H}_{2} \mathrm{SO}_{4}$ & 8.76 & 0.300 & 7.24 & 0.29 & 0.260 & 11.5 & 2.470 & 0.61 & 0.20 \\
\hline Redistilled water & 41.48 & 0.350 & 10.9 & 0.58 & 0.135 & 1.30 & 1.825 & 4.86 & 0.25 \\
\hline Deionized water & 50.01 & 0.367 & 8.43 & 0.95 & 0.238 & 1.90 & 1.710 & 8.71 & 0.19 \\
\hline
\end{tabular}

$\dagger c f$. Table I; $\dagger$ Estimated from ${ }^{39} \mathrm{~K}^{+}$ion beam current

Table VI Replicate analyses of calcium in the presence of large excess of foreign components : Galcium in sea water and in polar snow ice

\begin{tabular}{|c|c|c|c|c|c|c|c|c|c|}
\hline Sample & $\begin{array}{c}\text { Sample } \\
\text { taken }\end{array}$ & $\begin{array}{c}{ }^{42} \mathrm{Ca} \\
\text { spike added } \\
\left(\times 10^{-7} M\right)\end{array}$ & $\begin{array}{c}{ }^{42} \mathrm{Ca}^{+} / \\
{ }^{40} \mathrm{Ca}^{+} \\
\text {measured }\end{array}$ & $\begin{array}{l}\text { C. V.† } \\
(\%)\end{array}$ & $\begin{array}{l}\text { Ca found } \\
(\mu \mathrm{g})\end{array}$ & $\begin{array}{c}\text { Ca concn. } \\
(\mathrm{ppb})\end{array}$ & $\begin{array}{c}{ }^{40} \mathrm{Ca}^{+} \text {ion } \\
\text { beam current } \\
\left(\times 10^{-14} \mathrm{~A}\right)\end{array}$ & $\begin{array}{c}{ }^{40 \mathrm{~K} \dagger \text { ion }} \\
\text { beam current } \\
\left(\times 10^{-17} \mathrm{~A}\right)\end{array}$ & $\begin{array}{l}\text { Filament } \\
\text { current } \\
\text { (A) }\end{array}$ \\
\hline Sea water & $\begin{array}{r}10.8 \mu l \\
10.7 \mathrm{\prime \prime} \\
5.4 \mathrm{\prime \prime} \\
5.6 \mathrm{\prime l}\end{array}$ & $\begin{array}{l}0.595 \\
0.589 \\
0.522 \\
0.546\end{array}$ & $\begin{array}{l}0.504 \\
0.505 \\
0.824 \\
0.873\end{array}$ & $\begin{array}{l}0.52 \\
0.25 \\
0.42 \\
0.18\end{array}$ & $\begin{array}{l}4.33 \\
4.28 \\
2.27 \\
2.24\end{array}$ & $\begin{array}{l}401 \times 10^{3} \\
400 \times 10^{3} \\
421 \times 10^{3} \\
400 \times 10^{3}\end{array}$ & $\begin{array}{c}4.93 \\
18.99 \\
7.53 \\
67.4\end{array}$ & $\begin{array}{c}0.022 \\
75.6 \\
0.17 \\
254\end{array}$ & $\begin{array}{l}2.220 \\
1.760 \\
1.940 \\
2.010\end{array}$ \\
\hline Polar snow ice & $\begin{array}{l}20.17 \mathrm{~g} \\
20.18^{\prime \prime} \\
10.22^{\prime \prime} \\
10.12^{\prime \prime}\end{array}$ & $\begin{array}{l}0.203 \\
0.182 \\
0.300 \\
0.286\end{array}$ & $\begin{array}{l}6.98 \\
6.64 \\
12.3 \\
11.6\end{array}$ & $\begin{array}{l}0.32 \\
0.11 \\
0.51 \\
0.30\end{array}$ & $\begin{array}{l}0.0686 \\
0.0666 \\
0.0323 \\
0.0360\end{array}$ & $\begin{array}{l}3.40 \\
3.30 \\
3.16 \\
3.56\end{array}$ & $\begin{array}{l}9.58 \\
9.16 \\
8.59 \\
8.80\end{array}$ & $\begin{array}{l}0.26 \\
0.026 \\
0.16 \\
0.000\end{array}$ & $\begin{array}{l}1.600 \\
1.645 \\
1.670 \\
1.410\end{array}$ \\
\hline
\end{tabular}

$\dagger c f$. Table I 
Table VII Ghemical constituents in snow ice from West Enderby Land, Antarctica ${ }^{\dagger}$

\begin{tabular}{|c|c|c|c|c|c|c|c|c|}
\hline \multirow{2}{*}{$\begin{array}{l}\text { Sampling } \\
\text { station }\end{array}$} & \multirow{2}{*}{ Latitude and longitude } & \multirow{2}{*}{$\begin{array}{l}\text { Date of } \\
\text { sampling }\end{array}$} & \multicolumn{5}{|c|}{ Concentration $(\mu \mathrm{g} / \mathrm{kg})$} & \multirow{2}{*}{$\begin{array}{c}\text { Silicate } \\
\text { dusts }\end{array}$} \\
\hline & & & $\mathrm{Na}$ & $\mathbf{K}$ & $\mathrm{Mg}$ & $\mathrm{Ca}$ & $\mathrm{Ti}$ & \\
\hline $\mathrm{S} 122$ & S 70.01 .1$, E 43.06 .5 & Jan. 18,1971 & 53 & 2.1 & 13 & 3.18 & 0.04 & 8 \\
\hline Mizuho-1 & S 70.42 .1 , E 44.17 .5 & Nov. 17, 1970 & 14 & 1.2 & 2.1 & 2.78 & 0.01 & 2 \\
\hline Mizuho-2 & " , " & Jan. 9,1971 & 14 & 0.88 & 2.4 & 1.89 & 0.00 & 0 \\
\hline Y135 & S 71.26 .8$, E 47.21 .8 & Nov. 24, 1970 & 12 & 1.0 & 3.0 & 1.81 & 0.06 & 12 \\
\hline Y200 & S 71.46 .1 , E 48.55 .6 & Nov. 27, 1970 & 14 & 1.0 & 2.3 & 3.76 & 0.03 & 6 \\
\hline Y300 & S 70.54 .9$, E 49.52 .9 & Dec. 4,1970 & 11 & 0.56 & 1.7 & 1.93 & 0.04 & 8 \\
\hline
\end{tabular}

$\dagger$ Collected by Hiromu Shimizu, The Institute of Low Temperature Science, Hokkaido University

Table VIII Determination of calcium in snow ice from West Enderby Land, Antarctica

\begin{tabular}{|c|c|c|c|c|c|c|c|c|c|c|c|}
\hline Sample & $\begin{array}{c}\text { Sample } \\
\text { taken } \\
\text { (g) }\end{array}$ & $\begin{array}{c}{ }^{42} \mathrm{Ca} \\
\text { spike } \\
\text { added } \\
\left(\times 10^{-8} M\right)\end{array}$ & $\begin{array}{l}\text { Filament } \\
\text { current } \\
\text { (A) }\end{array}$ & $\begin{array}{c}{ }^{42} \mathrm{Ca}^{+} \\
\text {ion beam } \\
\text { current } \\
\left(\times 10^{-14} \mathrm{~A}\right)\end{array}$ & $\begin{array}{c}40 \mathrm{~K}^{+} \dagger \\
\text { ion beam } \\
\text { current } \\
\left(\times 10^{-17} \mathrm{~A}\right)\end{array}$ & $\begin{array}{c}{ }^{42} \mathrm{Ca}^{+} J \\
{ }^{4} \mathrm{Ca}^{+} \\
\text {measured }\end{array}$ & C. V.t† & $\begin{array}{c}\text { Ca } \\
\text { found } \\
(\mu \mathrm{g})\end{array}$ & $\begin{array}{c}\mathrm{Ca} \\
\text { concn. } \\
(\mathrm{ppb})\end{array}$ & $\begin{array}{l}\text { Ca originating } \\
\text { in silicate dusts. } \\
\text { ppb in snow } \\
\text { sample }\end{array}$ & $\begin{array}{l}\mathrm{Ca} / \mathrm{Na}+{ }^{+}+ \\
\text {in atomic } \\
\text { ratio }\end{array}$ \\
\hline S122 & 20.11 & 3.34 & 1.865 & 5.41 & 0.093 & 9.87 & 0.32 & 0.0639 & 3.18 & 0.28 & 0.10 \\
\hline Mizuho-1 & 20.49 & 4.31 & 1.820 & 7.36 & 0.500 & 11.6 & 0.66 & 0.0570 & 2.78 & 0.07 & 0.34 \\
\hline Mizuho-2 & 20.38 & 3.84 & 1.595 & 2.89 & 0.008 & 12.8 & 0.57 & 0.0386 & 1.89 & 0.00 & 0.23 \\
\hline Y135 & 20.54 & 2.82 & 1.865 & 8.85 & 0.000 & 11.6 & 0.66 & 0.0873 & 1.81 & 0.42 & 0.26 \\
\hline Y200 & 20.46 & 4.50 & 1.505 & 1.97 & 0.930 & 10.4 & 0.41 & 0.0768 & 3.76 & 0.21 & 0.47 \\
\hline Y300 & 20.37 & 3.18 & 1.730 & 7.59 & 0.220 & 11.9 & 0.22 & 0.0393 & 1.93 & 0.28 & 0.30 \\
\hline
\end{tabular}

$\dagger$ Estimated from ${ }^{39} \mathrm{~K}^{+}$ion beam current; $\dagger \dagger c f$. Table I; $\dagger \dagger \dagger$ Value in sea water $=0.063$, New Byrd, Antarctica $=0.070$ (summer), 0.061 (winter), Camp Century, Greenland $=0.14$ (fall), 0.43 0.68 (winter), 1.98 (spring), 0.73 (summer)

についてはすでに報告した7).

3.3.2 自量分析 2.2 .2 の方法により, 試料 $20 \mathrm{~g}$ に $1^{10-8}$ モルの ${ }^{42} \mathrm{Ca}$ スパイクを添加し, ${ }^{42} \mathrm{Ca}+/{ }^{40} \mathrm{Ca}+$ が 10 に近い条件下で, $0.75 \times 10^{-9}$ ないし $2 \times 10^{-9}$ モ ル，すなわち 0.03 ないし $0.08 \mu \mathrm{g}$ のカルシウムを定 量した (Table VIII). 精度は ${ }^{42} \mathrm{Ca}+/{ }^{40} \mathrm{Ca}+$ 測定の変 動係数として，0.22 ないし $0.66 \%$ であった. しかし試 料調製より質量分析完了までの全操作のくりかえし分析 では, 試料量が $20 \mathrm{~g}$ のとき $(3.35 \pm 0.05) \mathrm{ppb}, 10 \mathrm{~g}$ で は $(3.36 \pm 0.20) \mathrm{ppb}$ となり，平均值よりのかたよりは それぞれ 1.5 および 6\% となった(Table VI).

3.3.3 同位体平衡本法は式 (1) の同位体平衡が 成立することを基本条件としている. さて雪水中のカル シウムの起源は主として 海洋源の 風送塩と大陸源のケ イ酸塩鉱物微じんである. 本法の試料調製法 $(2 \cdot 2 \cdot 2)$ に よれば, ${ }^{12} \mathrm{Ca}$ スパイクとケイ酸塩鉱物中のカルシウムと の間に同位体平衡が不成立のおそれがある. この種の力 ルシウムが同位体平衡に達する次の機会はイオン源フィ ラメント上で共存成分とともに強熱されることである が，同位体平衡が成立したことを実験的に確認するにい たっていない，同位体平衡が不成立の場合には本法は相 応の過小值を与えることとなる.

さて，ケイ酸塩鉱物微じん中に含有されるカルシウム 量を次のようにして評価し，たとえ同位体平衡が不成立 の場合でも影響は少ないものと考えることができた．雪
片の凝縮核となっているケイ酸塩鉱物微じんは大陸源の 粘土などが主であっで9，チタン含有量は 0.46 ないし $0.63 \%$ (原子比) ${ }^{10)}$ ，カルシウムはその 6 ないし 8 倍平 均 7 倍である. 雪片中のチタンは海洋源のものは無視し うるから，チタンを定量することによってケイ酸塩鉱 物微じん源のカルシウムを近似的に知ることができる8) (Table VIII).

すなわち，鉱物源カルシウム量は本法によるカルシウ ム量の $10 \%$ 程度にすぎず，たとえ ${ }^{42} \mathrm{Ca}$ スパイクとこ の種のカルシウムの間に 同位体平衡の不成立があって も，大きな影響を及ぼすものとは考えられない。

\section{4 結語}

\section{1 地球化学への応用}

本法を地球両極地方の雪水に応用して次の事実を明ら かにすることができた. カルシウムなどの主成分濃度は 過去 200 年の降雪中では変化が小さい. 雪質をナトリウ ムとカルシウムの原子比で表わす (Table VIII) と, 南 極大陸内部の Byrd Station では海水值に近いが， Enderby Land ではカルシウムが相対的に増大している. この増大量はケイ酸塩鉱物微じん源のカルシウムの量を 明らかにこえるものであるから，海洋塩の風送中にお ける成分分化のためと考えられる. グリーンランドの Camp Century においてはナトリウムとカルシウムの原 子比に季節変化が存在し, 冬から夏にかけてカルシウム 
の割合が増大することが認められた

\section{2 分析化学上の問题点}

${ }^{40} \mathrm{~K}+$ と ${ }^{40} \mathrm{Ca}+$ のイオンビームの重複が, 最も憂慮さ れたが，低フィラメント電流值においてベーキング処理 することによりカリウムイオンを減衰させることができ た.このことは, 試料に ${ }^{41} \mathrm{~K}$ と2 $\mathrm{Ca}$ 両スパイクを同 時に添加して試料を調製し，まず前報2）によりカリウム を定量したのちフィラメント電流值を上昇させてカルシ ウムを定量するという逐次分析法への道をひらくことと なった11).

(1967 年 4 月 2 日, 日本化学会において一部発表)

\section{交献}

1) 成瀬廉二, 遠藤八十一, 成田英器, 山田和充 : 南 極資料，45，33 (1972).

2) 室住正世, 中村精次 : 本誌, 22, 145 (1973).

3）日本放射性同位元素協会：“アイソトープ便覧”, p. 428 (1962).

4) M. Murozumi, H. Shimizu : JARE DATA REPORTS, 17, 132 (1972).

5) 室住正世, 中村精次, C. C. Patterson : 本誌, 19, 1057 (1970).

6) 室住正世, 新名朋次 : 化学の領域, 26, 39(1973).

7) M. Murozumi, T. J. Chow, G. C. Patterson : Geochim. Cosmochim. Acta, 33, 1247 (1969).

8) 室住正世, 中村精次, 新名朋次, 清水 弘: 地球 化学討論会要旨集, p. 48 (1972).

9) K. Kumai, K. E. Francis : J. Atm. Sci., 19, 474 (1962).

10) V. M. Goldschmidt : Geochemistry, 411 (1962). Y. Miyake : "Elements of Geochemistry", p. 292 (1965).

11) 室住正世, 中村精次 : 日本分析化学会北海道支部 1973 年冬季研究発表会講演要旨, p. 3A 14 (1973).

$$
\text { 它 }
$$

Isotope dilution mass-spectrometry of calcium. (Determination of chemical components at the ppb level in both polar snow strata. IV.) Masayo MurozUmi and Seiji NAKamura (Muroran Institute of Technology, 27, Mizumoto-cho, Muroran-shi, Hokkaido)

Isotope dilution mass-spectrometry can be applied to the determination of minute amounts of calcium in distilled water, deionized water and snow melts from ice sheets in Greenland and Antarctica. The amount of sample required is $20 \mathrm{~g}$ for snow analysis.

In a $100 \mathrm{ml}$ teflon beaker, $0.3 \times 10^{-7} M$ of ${ }^{42} \mathrm{Ca}$ spike in $0.06 \mathrm{~g}$ of dilute nitric acid is accurately weighed. Snow melt is poured directly into the beaker from the agitated sample bottle and is weighed. The mixture is evaporated to $50 \mu l$ in a heated steel tank in which high purity nitrogen gas is streaming. Small drops of the concentrated liquid are loaded onto the tantalum filament by using a quartz micropipette.

The ion source used is equipped with a specially designed single filament unit which is heated with accurately controlled electric çurrent. This emits intensive $\mathrm{Ca}^{+}$beams from $10^{-10} \mathrm{~g}$ bf calcium salts loaded on the filament.

The coefficient of variation for the peak height ratio of ${ }^{42} \mathrm{Ca}$ to ${ }^{40} \mathrm{Ca}$ ranges between 0.22 and 0.66 percent and is not affected by the coexistence of foreign substances. The degree of isotope effects is reduced to a minimum under 1 percent by running the mass-spectrometer under common conditions. Calcium and potassium have the isobars with the mass number of 40 , but the isobar effects can be reduced to a negligible quantity by baking treatments.

Snow melts contain minute amounts of silicate mineral dusts which have played important roles as the nucleation centre for water vapour at the formation of snow flakes. So it is important that calcium added as a spike is equilibrated isotopically with that in the silicate mineral dusts. If it is not so, calcium isotopes i. a salt matrix may be more easily released from the heated filament than those combined with the silicate matrix, and this will result in lower value of calcium. From the content of titanium, calcium from the silicate mineral dusts accounts for nearly 10 percent of total calcium in snow melts, while the remaining calcium occurs in sea salts predominantly.

The concentrations of calcium are found to be 1.9 $\mathrm{ppb}$ in both redistilled and deionized water, $2 \mathrm{ppb}$ in snow melts of West Enderby Land, Antarctica, and several ppb in those of Camp Century, Greenland. In greenland snow strata, calcium concentrates in winter layers as well as dusty components. In both the polar regions, no appreciable variations of calcium concentration have been detected in whole year composite samples since 1750 .

(Received Mar. 22, 1973) 